\title{
LEISURE ON THE CHINESE EASTERN RAILWAY: YACHT CLUB AND RACECOURSE AS “OTHER SPACES” OF HARBIN
}

\begin{abstract}
Alexander Yu. Meshcheryakov
National Research University "Higher School of Economics University”. St. Petersburg, Russia. Email: daomesheryakov[at]gmail.com
\end{abstract}

\begin{abstract}
Applying Fr. D. Turner's frontier theory and M. Foucault's concept of heterotopic spaces the author studies "other" spaces created by Russian railway men and Cossacks in Northern Manchuria in the late 19th - first half of the 20th centuries. Particular attention is paid to the organization of leisure in Harbin. The article considers two quite interesting spaces: the yacht club on the bank of the river Sungari and the hippodrome. The choice of these leisure spaces was based on a number of important characteristics. The purpose of this study is to analyze the spaces of the yacht club and the hippodrome as heterotopic spaces on the frontier territory. The author reaches several important conclusions about the basic principles of the basic principles of the creation and the functioning of these leisure spaces. Within these spaces, many cultural processes took quite different forms. The article provides numerous previously unknown facts about the development of yachting and trotting in Harbin.
\end{abstract}

\section{Keywords}

CEL; Harbin; Yacht Club; Racecourse; Northern Manchuria; China; Russia; railway men; Cossacks; leisure; leisure spaces

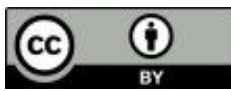

This work is licensed under a Creative Commons «Attribution» 4.0 International License 


\title{
ДОСУГ НА КИТАЙСКОЙ-ВОСТОЧНОЙ ЖЕЛЕЗНОЙ ДОРОГЕ: ЯХТ-КЛУБ И ИППОДРОМ КАК «ДРУГИЕ ПРОСТРАНСТВА» ХАРБИНА
}

\author{
Мещеряков Александр Юрьевич \\ Национальный исследовательский университет «Высшая школа экономики». \\ Санкт-Петербург, Россия. Email: daomesheryakov[at]gmail.com
}

\begin{abstract}
Аннотация
Применяя фронтирную теорию Фр. Д. Тернера и концепцию гетеротопных пространств М. Фуко автор изучает «другие» пространства созданными российскими железнодорожниками и казаками в Северной Маньчжурии в конце XIX - первой половине XX вв. Особое внимание в работе уделяется организации досуга в Харбине. В статье рассматривается два достаточно интересных пространства: яхт-клуб на берегу р. Сунгари и ипподром. Выбор именно этих досуговых пространств был основан на ряде важных характеристик. Целью данного исследования является проанализировать пространства яхт-клуба и ипподром как гетеротопные пространства на фронтирной территории. В результате автор охарактеризовал основные принципы создания и функционирования этих досуговых пространств. Внутри этих пространств многие культурные процессы принимали совершенно иные формы. В статье приводятся многочисленные факты развития яхтинга и рысистого дела в Харбине. Российские железнодорожники меняли в Северной Маньчжурии почти все, в том числе и досуговые пространства.
\end{abstract}

\section{Ключевые слова}

КВЖД; Харбин; Яхт-клуб; Ипподром; Северная Маньчжурия; Китай; Россия; железнодорожники; казаки; досуг; досуговые пространства

Это произведение доступно по лицензии Creative Commons «Attribution» («Атрибуция») 4.0 Всемирная 


\section{INTRODUCTION: PROBLEM STATEMENT}

This article explores several aspects of leisure in Harbin during the formation of the new frontier. One of the important aspects of leisure is the creation of a new order of space and time during the struggle for spheres of influence in Manchuria. I find it essential to study the efforts by railroad engineers to create a supportive environment to meet their needs outside of their usual territories and living conditions. I will show, using two types of leisure spaces as examples, how the technocratic elite shaped "other" imperial spaces in Northern Manchuria. Leisure spaces are examined using the example of the Harbin Yacht Club and Racecourse. These were spaces of competition and confrontation as well as the imposition and defense of the interests of the Russian, Chinese and Japanese elites on the RussianChinese frontier. The creation of such leisure places was aimed at the socialization of space. The study of leisure spaces allows us to better understand the history of Harbin and its people in the late $19^{\text {th }}$ - first half of the $20^{\text {th }}$ centuries.

Leisure spaces, like leisure time itself, are very important in the study of frontier history. A person is shaped not only at school or at work, but also in their free time. In the book by the American writer Martin Woodside there is an imperative: "Go West, young man, and grow up with the country" (Woodside, 2020, p. 3). I would like to change the well-known imperative a bit and say, "Go to Siberia, to the Far East, young man, and grow up with the Empire". But the East is not the West, and Siberia is not California, although Siberia was a territory with all sorts of liberties, it was also a territory of exile, penal servitude, and the strictest disciplinary practices. In the process of conquering this or that frontier, several generations succeeded, organizing their leisure and entertainment spaces over many decades. In the late $19^{\text {th }}$ century, during the construction of the Trans-Siberian Railway and the CEL, railway engineers viewed Siberia in quite a different way. In 1895 M. N. Gersevanov, the director of the Institute of Railway Engineers of Alexander I, in his speech to the first-year students, noted: "By order of ... Emperor Alexander III, Siberia is now being transformed from a place of exile into a country with a brilliant future, a country presenting a vast arena for every technician and industrialist, and above all for those pioneers of civilization who are called the engineers of the railways" (Miscellaneous news, 1895, p. 128). M. N. Gersevanov spoke at a moment when railroad workers were displacing Cossacks as dominant social group shaping Siberian leisure spaces.

At the end of the $19^{\text {th }}$ century in undeveloped Manchuria, the leisure of railway engineers, officers and Cossacks was limited to drinking, talking, 
playing cards, fishing, hunting ${ }^{1}$, reading, horseback riding and hiking, etc. (Meshcheryakov, 2019, p. 185). Remote spaces like Manchuria were harsh, uninhabited, wild territories without basic amenities and with all sorts of challenges. The centers of leisure and entertainment in such areas tended to be pubs, taverns, bars, brothels and gambling houses. The presence of such spaces can be seen in the various frontiers during the colonial era. Russian General Krasnov P. N. wrote in 1901 about living conditions in Manchuria and the CEL: "To serve here you either have to drink, or gamble, or hunt... only engineers live here, and they have so much fun that more than one of them has committed suicide" (Krasnov, 1903, p. 64).

The harsh living conditions in the Manchurian taiga, the constant restrictions and liberties influenced the formation of the idea of a new and modern urban space. At the end of the $19^{\text {th }}$ century, it seemed to engineers that new technology and uninhabited territories offered limitless possibilities for creating the city of the future. Harbin was designed as a "paradise" on the banks of the Sungari River. The utopian ideas of progressivism suggest that peace, prosperity, and good health are attainable through technology. According to a maxim by B. V. Ostroumov, Russian engineer and manager of the CEL: "An engineer is a creator! On him lies the sacred duty of arranging the Earth. An engineer by vocation should spend all his life with a worrying and burning desire for new improvements. When an engineer comes to the desert, the desert would be covered with a network of roads, new cities appear on it, gardens blossom, croplands are filled with the juices of the earth, life becomes beautiful' (See (Avenarius, 1969-1979)). Similar progressive utopian ideas dominated the minds not only of Russian railroad workers, but also of Japanese military and engineers. General Araki Sadao, Minister of War and ideologist of Japanese foreign expansion, declared, "We have fought for Manchuria for thirty-five years in two wars where fapanese blood has flowed like a river. Manchuria is valuable to us not only economically, but also strategically... We want to make this country an earthly paradise, where everyone can live and flourish. We will not allow it to be attacked or corrupted" (See (Molodyakov, 2020, p. 61).

During Manchu-Go period Japanese colonizers/developers believed that Harbin was rapidly approaching the level of a modern Japanese city, both in name and in innovation (Denison, E. \& Ren, G., 2016, p. 85). For the Japanese, Manchuria was a huge laboratory where a new generation of Japanese architects and engineers gained unprecedented experience and opportunities to create modern designs (Denison, E. \& Ren, G., 2016, p. 58).

1 About the Railway Traffic Inspector: Fishing and Hunting; Devoting himself with ardent passion; He is at work; Only by "misfortune" (Poems, feuilletons and fiction. Railroad Silhouettes, 1908, p. 68). 


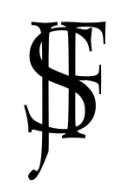

Today, the idea of paradise does not lose its relevance in the urban concept of Harbin. Now Harbin continues to compete vigorously with China's largest cities. The main goal of this rivalry is to elevate itself into a modern metropolis. According to the Chinese government's development strategy, the city is expanding to the North and South, restoring central areas and reinforcing districts. The ultimate goal is to transform Harbin into an urban space with high technology, culture, trade and commerce. At the moment, Harbin is developing on both sides of the Sungari River. The restoration of the central areas of the city aims to improve its facilities and restore the European style of the city (Ben-Canaan, 2010).

It is important to note that one of the first railway stations in the Russian Empire, located on the Tsarskoye Selo railroad, was designed by railway engineers as a leisure space for aristocrats. A theater, a garden, a public park with a pavilion, and a veranda were built into the station's space. Thanks to a permanent musical program, balls and, later, themed concerts, the station became an important space in the formation of Russian culture in the $19^{\text {th }}$ century (Klyuchnikova, 2020).

In this article I will try to show how the heterotopic spaces of the yacht club and the hippodrome were embedded in the overall natural and cultural landscape of Harbin. I also intend to explore the history of these two social institutions. I will studied not only these two places, but also the open space of the Sungari River. Additionally, I will also describe the perception of seasonal cyclicity and climate in Harbin. Leisure time is always connected with seasonal cyclicity, as it determines the organization of free time and people's behavior.

\section{RESEARCH METHODOLOGY}

Before proceeding to a direct analysis of the problem stated in the title, I will discuss the methodology and concepts applied in my research. This study is based on F. J. Turner's frontier theory and M. Foucault's concept of heterotopia. Leisure spaces in frontier areas are predominantly heterotopias. Within these spaces everything is ordered, there are strict rules and free patterns of spectator behavior prescribed by the authorities. By heterotopia M. Foucault understood the "other" as a special space that includes many spaces. According to him, spaces are initially utopias, and then turn into heterotopias. Foucault distinguished six principles of heterotopic spaces on the basis of which various loci (locus) can be analyzed (Foucault, 1986, pp. 22-27). Heterotopias take different forms; there is no single form of heterotopia that is completely universal (Foucault, 2006, p. 197). M. Foucault believed that it is possible to describe places of temporary recreation - cafes, cinemas, beaches, etc., through a cluster of relations (p. 195). 


\section{MAIN PART}

The Russian historian Sergey. N. Yakushenkov writes that as a result of cross-cultural contacts a new cultural reality is formed, which combines the features of all actors of the frontier process. However, this new reality develops according to its own laws dictated by the frontier situation as a whole. The new cultural reality is the result of combining several cultural landscapes within a single natural landscape (Yakushenkov, 2019, p.17).

At the end of the XIX century, Russian railroad workers built a new imperial city in undeveloped Northern Manchuria - Harbin. This city was positioned as an extraterritorial experiment in Asia and was part of Russian imperial strategy. It is important to note that the territory where the CER was laid and Harbin was built was leased from China as a result of RussianChinese negotiations in 1896 (Lukoyanov, 2008, p. 100). This hub of the CEL was to become the economic and political center of "Asian Russia" in the Far East. The Russian government had several opinions on the issue of annexing the leased territory of Northern Manchuria to the Russian Empire. At the end of the XIX century, a completely different model of imperial space began to be created in Manchuria, which could not be found in other territories.

Transferring space to undeveloped territory, incorporating and imitating the spaces of the metropolis is a colonial manifestation of power, involving the subjugation of new territory. It is no coincidence that the British planted their gardens at embassies and other state institutions in the colonial territories. And the Japanese, during the formation of Manchukuo, planted a large number of cherry trees in Harbin along the banks of the river, which runs in the Nangang district and crosses the wide Gogol Street (See The Japanese map of Harbin, 1939). Today, these gardens no longer exist and in their place paved embankments have been built in Harbin. The Nangang area (南岗区, Nangang - South Bank of the Sungari River) was home to gardens, parks, government offices, the famous Yamato Hotel, residences of wealthy merchants and officials (Denison, E. \& Ren, G., 2016, p. 83).

Harbinians incorporated innovations and spaces from all over the world - Paris, London, St. Petersburg, Beijing, Odessa, Shanghai, New York, San Francisco. Harbin was not accidentally formed as a city of yachts, races and new imperial gardens, where sakura and birch trees grew in the beer and wine gardens, with Chinese verandas and gazebos for relaxing, all kinds of restaurants and kitchens and much more. In different periods, the spaces of the city were rearranged in the process of changing power. While the Russian Empire was new to Manchuria and formed a political center there, Japan was able to subjugate the territory temporarily but fully. In the end, China, with 


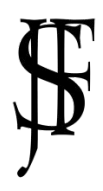

Журнал Фронтирных Исследований. 2021. No 3 | ISSN: 2500-0225

Фронтир в мировом контексте | Doi: https://doi.org/10.46539/jfs.v6i3.314

the support of the Soviet Union in the mid-20th century, made the territory an independent and uncontested property of China. Today, the frontier city of Harbin remains a hybrid, its urban landscape renders a clear evidence.

I believe that certain leisure forms are an indicator of imperial space. The Racecourse and Yacht Club in Harbin are predominantly male spaces, as they were originally conceived as places of competition and rivalry. Harbin initially was formed, perceived, manifested as a masculine space for the comfortable life and work of Russian railway workers. In this city, new places were created for modern and comfortable living in a multicultural way. The yacht club and the racecourse are a different awareness of leisure and a new model of social space in the early XX century. These spaces were not formed for ordinary workers, but for the technocratic elite and officers. In these spaces we can trace the established symbols of aristocracy - competition involving the use of a horse or yacht, rivalry, battle, and communication.

\section{KARAUL! ... OH, HIGHER LEGS! ... WHERE ARE THE BOATS? ... GIVE ME THE ROPE! ... ${ }^{1}$}

In many cultures, the sea and rivers are important loci (locus) for leisure activities. Boat competitions (including boat building) are common leisure activities in Southeast Asia. Sword fighting, archery, and various forms of competition have been popular male entertainment for the Chinese aristocracy for several centuries. And many pre-colonial entertainments among the common people, such as kite flying, cockfighting, bamboo stilt racing, and playing takrou, required special skills and dexterity (Moser, S.; Clinton, S.; Wallach, J., 2017 p. 110).

During the colonial period, as a result of the Industrial Revolution, the development of technology and communications, the strengthening of communication between the metropolis and the colonies, and the borrowing of cultures, many aspects of European life (including leisure practices) became increasingly common in Asia. The first yacht club in Southeast Asia was founded by British colonists in Singapore in 1826. The British also established parks and botanical gardens in Singapore in 1859. Today, these gardens and the yacht club in Singapore are tourist attractions (p. 112).

In Russian culture, it is enough to recall a well-known activity of the Russian tsars in history - falconry. Initially, hunting was not an entertainment among the common population, but was positioned as a way to earn money and survive. There is no doubt that Russian culture incorporated European leisure activities through the elites. For example, Peter the Great's famous boat rides on the Yauza River or canoeing by Nikolai II stemmed from

1 The first lines are from Loulou's piece on the Harbin flood (in Russian: Караул!... Ой, выше ноги!... Лодки где? ... Давай канат! ...) (Loulou, 1909, p. 845). 
the Romanov's fascination with European culture ${ }^{2}$. It should not be forgotten that elites, like other members of society, are subject to historically-determined disciplining discourses. In the history of Russia, as in many other countries, initially the elite itself learned to organize leisure time - to test and it and to experience it, and subsequently to form free time and spaces for its own entertainment within the framework of the culture to which the elite adhered in this or that historical period. Part of the population followed the example of the authorities, and the dissenting population was sooner or later forced to adopt new ways and forms of leisure, which over time turned into the norm.

The natural landscape of Manchuria largely determined the leisure activities of the population. The space of the Sungari River contributed to the idea of organizing a yacht club on the shore. The Sungari, as the most prominent part of Harbin's urban space, was described by Harbiners as part of urban life from various points of view, such as transportation, water supply or the threat of flooding, recreation, etc. The section of the Sungari from Harbin to the confluence of the Mudanjiang River is described as mountainous and level. "Native river. Not ours, not Russian, yellow, muddy - but so dear and close to our hearts - we were born and grew up with it... From my early childhood, in summer, in the heat, there were no more desirable words than: "Let's go to Sungari River"... Wide, treacherous, but tempting, cool, relentlessly carrying its yellow waters to some unknown place, to unknown distance... Under the descent to the shore there are boats. They are painted in interesting colors, white, green and red... Or maybe a powerboat? It smells so comfortably of gasoline..." (Polytechnic, 1975, p. 105). "And always good you were, Sungari! In the early morning calm, in grayish tones, motionless, smelling of sharp river dampness, quiet, peaceful. Boats rushing down the river... In the gray haze, a railroad bridge, almost a kilometer long; a train running across it" (Chemodakova, 1978, p. 237). "The Sungari is also nice in the daytime, sunny and hot. Slightly warm, yellowish-golden in the sun and dark... The hustle and bustle on the embankment: the squealing of children, the laughter of young people - summer vacation. Fishermen with fishing rods somewhere down on the shore; Chinese women rinsing their laundry" (Chemodakova, 1978, p. 237). The Sungari was also a favorite place for fishing enthusiasts (Zhernakov, 1969-1979, p. 104). Advertisements oriented toward recreational activities on the river can often be

2 On March 27, 1894 Nicholas II wrote in his diary: "At 91/2 we went to the garden for a walk; the weather was perfect, the air was truly invigorating... I opened with Misha the navigation, having ridden in kayaks..." (Diaries of Emperor Nicholas II. 1894-1904, 2011, p. 62); on May 7, 1898 he recorded in his diary: "At 3 o'clock we returned to Tsarskoye. Received Goremykin, went to the pond and kayaked...” (Diaries of Emperor Nicholas II. 1894-1904, 2011, p. 406); June 2, 1895 "Made a trip with Misha on bicycles, and then in kayaks in the sea. It was fresh and we were gloriously doused by the waves. After tea I read and went out to sea again. After paddling and wind you feel more awake!" (Diaries of Emperor Nicholas II. 1894-1904, 2011, p. 206). 


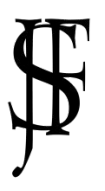

found in the pages of periodicals, e.g. "The best outboard Johnson motors in the store of Skoblin and Co" (Harbin Herald, The Yacht Club prepares for the season, 1930, p. 9); "All for fishing: rods, reels, lines, hooks Norwegian, English, German” (Rubezh, All for Fishing, 1929, p. 21), etc.

Yacht Club Harbin was founded in 1912 on the banks of the Sungari River near the Wharf with the aim of developing water and other sports (Ternavsky, 1926, p. 135). This space was built in a hybrid style, incorporating elements of European and Asian architecture, but has been continually rebuilt over time with modern technology and lighting (The Yamato Hotel \& The Yacht Club in Harbin, 1940, p. 342).

The waterfront was the most visited place in Harbin. The yacht club was designed as a special recreation area and was the main entertainment center on the banks of the Sungari (Harbin's urban heritage, 2015, p. 147). I believe that originally the yacht club was designed and built in the style Art Nouveau. The Russian historian S. S. Levoshko notes that in Russian urban planning at the turn of the $19^{\text {th }}-20^{\text {th }}$ centuries, the main function of architecture was the transformation of life (Levoshko, 2003, p. 62). Art Nouveau is characterized by open and glazed rooms (verandas, conservatories), linking the main room with the environment (Levoshko, 2003, p. 72). In the yacht club, two spaces were juxtaposed - natural and artificial, club's style modern in the technical sense.

The space of the yacht club was modeled not only by Russian engineers, but also by the Chinese, and after the formation of Manchukuo-Di-Go by the Japanese. In 1926 the Yacht Club committee was headed by General Ma Zongjun, engineer A. A. Eysymont, and Commander V. I. Korzin (Ternavsky, 1926, p. 135). A newspaper announcement in 1941 stated that the Yacht Club restaurant was recruiting employees of Russian and Manchurian nationalities for the positions of doorman, cook, waiter, and dishwasher (Harbin time, Announcement in view of the upcoming opening for the summer season, 1941, p. 4). The restaurant served the entire population of Harbin, and the chefs worked according to the same principles as the famous kitchen of Harbin "Yamato" Hotel (The Yamato Hotel \& The Yacht Club in Harbin, 1940, p. 342).

Steamships arriving on the banks of the Sungari with the first builders and construction materials, unloaded on the stretch of coast between the future Kitayskaya Street and Yacht Club. At the beginning of the $20^{\text {th }}$ century the Pier (Pristan') was a swampy place (Tairov, 1974, p. 37), which was gradually built up and improved. "Pristan' - merchants and dark dealers. The pubs, brothels, cards, brothels, opium parlors", - wrote the author Alymov S. Ya. in 1928 (See (Krotova, 2019, p. 760). Merchants and all kinds of businessmen built warehouses, hotels, trading houses and residential areas along the banks 
of the Sungari River, since the coastal piers, where barges and steamships were unloaded, were nearby. Engineers insisted on building new neighborhoods above the shoreline (Kradin, 2001, p. 48). Railroad Engineers and architects, accounting for floods, were not prevented by the Sungari bank from building the yacht club on piles above the shore. The Wharf District (Pristan') was developed on the private initiative of Harbin residents. It was the bank of the Sungari River that was the center of attraction and leisure locus since the beginning of Harbin's development and in subsequent years, despite the floods and the complexity of the natural landscape. In 1930 it was decided to move the veranda of the yacht club to a new place, because the beach under the veranda was repeatedly washed away during floods (Harbin Herald, Yacht Club, 1930, p. 5). The beach was rebuilt several times, as were many other buildings on the shore. Some spaces were moved to "poplavki" to reduce their vulnerability to natural conditions ${ }^{2}$.

By the 1930s and 1940s, the Sungari embankment had already been improved by new features such as various restaurants and a yacht club (Melikhov, 2003, p. 356). In 1940, the yacht club had its own garden, restaurant and night bar with the best food in Harbin. On the banks of the Sungari River along the yacht club grew a variety of palm trees. The cuisine in the yacht club restaurant was constantly improving and expanding. Every Saturday on the veranda of the yacht club, the most select society of Harbin gathered (Rubezh, Palms on the banks of the Sungari. Yacht club summer oasis of gourmets in Harbin, 1940, p. 16); (Rubezh, Summer Harbin, 1942, p. 6-7). "If you needed to treat someone or to conduct a banquet or just a business meeting, there could be no better place than the "Yacht Club" restaurant on the right bank of the Sungari River with a beautiful view of the river, the waterfront..." (Kozlovsky, Notes on the life of Harbin, 1979, p. 231).

"Passing through the revolving door, we enter into [in meeting members - A. M.] parlor studded with white and red beach parasols reminiscent of the Riviera. In a setting enhanced by unique architectural design chatting groups are seen who gaze with admiration at the scenery along the river bank. The lawn planted here and there with palms, with white benches, and wellcared for flower beds is a pleasant place to stroll. In the hall of the main building of the Yacht Club, with its sparkling chandeliers an atmosphere of wholesome freshness pervades. On the stage an ultra-modern orchestra trained to the highest pitch pours forth a melodious profusion of pleasant light music.

1 A floating barge with a superstructure. Similar floating structures can be seen on the banks of the Volga river in Astrakhan.

2 The floods that were destroying Harbin stopped only after the construction of the dam on the Sungari. In subsequent years, the Japanese managed to build the world's largest hydropower plant there. 
Russian food is served by neatly attired waiters at the luxuriously appointed tables placed on the veranda. From the veranda, one can observe the Sungari river flowing by in leisurely grandeur with reposeful tranquility. Every Saturday night, dances provide an evening's entertainment. Among noteworthy pieces which are asked for again and again are the Yacht Club March, specially composed for the establishment, and the Yacht Club Serenade which fully express the special characteristics of the club". In 1940, the Yacht Club and Yamato Hotel were the only and most prestigious tourist centers in Harbin (The Yamato Hotel \& The Yacht Club in Harbin, 1940, p. 343).

Ice drift on the Sungari ended in mid-April (Ternavsky, 1926, p. 23). Every spring the yacht club was constantly renovated for the new season. In 1930 the summer verandas were repaired and enlarged, the beach was put in order, new cabins were installed, a new cabin with a warm shower for vacationers was built. Every spring the yacht club was constantly renovated for the new season. Each veranda was protected from the rain. The repairs and preparation of the yachts, boats, and launches were completed in the spring. The official opening of the Yacht club for the new season took place in mid-May, and the opening of the beach at the end of May (Harbin Herald, Yacht Club prepares for the season, 1930, p. 6). On the opening day of the Yacht club, the flag was raised in the garden and on the veranda, which symbolized the beginning of its official activities in the new year: the restaurant was opened and a banquet was organized for the members of the yacht club (Harbin Herald, Yacht Club. The season is opened, 1930, p. 4). In addition to recreational activities sailing, rowing, track and field, and fishing sections were arranged (Harbin Herald, Yacht Club. The Resolution of Sports Commission, 1930, p. 6). Periodically, the yacht club hosted a ball on the veranda, and arranged motor races, a rowboat parade, evening boat rides, large garden strolls and other sorts of entertainment (Harbin Herald, Yacht Club Ball, 1930, p. 4-5). Crowds of Harbinians gathered on the embankment from Artillery Street to the Yacht Club to watch the yacht and motorboat races (Harbin Herald, Sungari Motorboat Competition, 1930, p. 5). In Harbin, many organizations emerged around basic institutions and private companies: sports clubs, political parties, libraries, charitable societies, social clubs, and more. Competitions of sailing yachts and boats were organized between Harbin private companies. For example, "Churin \& Co." had its own yachts, sports grounds, and often competed on the Sungari (Melikhov, 2003, p. 149). At the end of October the summer competition season on the Sungari River officially ended (Harbin Herald, In the Yacht Club 1930, p. 4).

Spaces and seasonal cycling are constantly interconnected, as seasonality determines the functioning of this space. Spring, summer and winter 
seasons determined the operation of the yacht club, as this space was embedded in the natural landscape and its location was determined by the Sungari River. Sungari. "The hot Manchurian summer, with its torrid and stiflingly humid breath, with its lush vegetation and unforgettable beauty of nature... As in previous years the bright sun, the invigorating air and the warm river waters..." (Rubezh, Sun, water and air - the joys of summer, 1945, pp. 10-11). "Summer. Heat, and stuffiness, and thunderstorms, sometimes with hail. But there was an escape from the heat - the wide, full-flowing, lovely Sungari River... Cool water, passing boats, low and double-decked, roaring engines, the smell of gasoline, the wave coming from the boats... Willows, wormwood and other grasses, stairs of summer houses going straight down into the water" (Chemodakova, 1978, p. 237). Summer temperatures in Harbin peaked at $29^{\circ} \mathrm{C}$ and $30^{\circ} \mathrm{C}$ and averaged $19-24^{\circ} \mathrm{C}$ (Ternavsky, 1926, pp. 20-21). "In the summer, especially on weekends, when the river was literally flooded with a stream of vacationers, the crossing was also carried out by large doubledeck boats of the Harbin Yacht Club, which for some reason were called "pampus"' - V. G. Melikhov recalled, a Russian historian who lived in Harbin from 1930 to 1946 (Melikhov, 2003, p. 368). "Spring with its smell of fresh sticky leaves, grass, bird cherry, lilac, and the thaw that preceded all this luxury after the harsh winter. The unique warm air, the thin ice in the mornings on puddles on which even though you don't want to, but you are sure to step to hear how it crunches... the green attire of trees, the "porridge" on them, eagerly eaten by Chinese children, and even later the down that flies from the slightest wind from the poplars" (Chemodakova, 1978, pp. 236-237).

Since the yacht club was founded on the Sungari River, annual sailing competitions have been held in the summer period. For example, in 1942 14 vessels participated in the races: seven yachts of the first category, five of the second category and two boats. "The strong wind blowing from the left bank allowed the boats not to maneuver, but to go one tack from one buoy to another". The first-class yacht "Tege", which completed the route in 36 minutes, was the winner of the Kio-Wa-Kai ${ }^{1}$ Championship Cup for three years. Anton Lavrinenko's yacht "Mermaid" (On the waves of the Sungari. Harbin championship yacht races, 1942, p. 34). won the cup. In addition to yachting, rowing and sailing were actively developed. Every year in the summer a swim of $3 \mathrm{~km}$ was organized down the river from the settlement of Chinhae to the site of the yacht club (Competition at the Yacht Club, 1930, p. 5). Figure skater Ablamsky V. P., who lived in Harbin until the arrival of Soviet troops in Manchuria in 1946, recalls: "In 1922 I, as

1 Since 1930 in the periodicals the name Kio-Wa-Kai stood for "Society for the Unification of the Peoples of the Manchurian Empire". In Manchu language, the society was called Se-He-Hoi (Yakovkin, 2018, p. 218). 


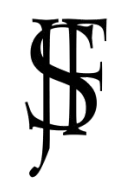

an eleven-year-old boy, engaged in the children's section of the Harbin Bicycle Society. A water sports department was splintered off from that society for rowing and sailing. Then a yacht club with a roadstead, where boats and yachts were located, was built near it by the CER. And on the left bank the stadium was tripled. There was also a hangar with racing boats. There were also jogging paths and a diving tower 5 meters high" (Ablamsky, 1998, p. 219).

Yachting as an option of active recreation on the Sungari River was also popular during the winter season. Engineer B. Kozlovsky writes in his article: "In addition to skating down the slopes, fans of sailing enjoyed sailing buoys on the ice. This construction was a triangular wooden frame with decking, which was put on skates: the front two skates were tightly attached to the two sides of the triangle base, and the third one was put at the top of the triangle, and it rotated in the bearing and served as steering. Sails and masts from summer yachts and boats were set and fastened in the center of gravity of the triangle... Unfortunately, the width on the Sungari in the area of Harbin did not exceed $3 / 4$ kilometer, and therefore there was not enough space for this sport... In a strong wind they were sailing on the ice cover at a speed of $70 \mathrm{~km}$ per hour" (Kozlowski, 1979, p. 230). This example shows that despite the harsh winters in Manchuria with severe frost and wind, the Harbins successfully organized leisure spaces on the Sungari in any season of the year.

"The Harbin winter, though harsh, had its charms and brought many pleasures and entertainment outdoors, whether it was an ice rink, a stadium, or the frozen Sungari. On the Sungari, nimble businessmen built tall artificial slides on the left bank, poured water over them, cleared a path on the snow-covered river, and set up twist-offs at the end of the path. They rented skids by the hour. The sleds were manageable, of varying sizes and the number of seats" (Kozlowski, 1979, p. 230). At the beginning of November the Sungari River froze over (Ternavsky, 1926, p. 23), the ice layer reached 3 feet thick, and the first snow fell in November (Pozdnev, 1897, p. 162). Winter temperatures in Harbin ranged from $-2^{\circ} \mathrm{C}$ to $-24^{\circ} \mathrm{C}$ (Ternavsky, 1926, pp. 20-21).

The Yacht Club and the Sungari River. The Sungari remained a recreational center in winter, around which new spaces were created for all kinds of entertainment. The entire population visited this area. In addition to the space of the Sungari River, the city was flooded with private skating rinks at schools, private houses with extensive yards, teplushki $i^{1}$, kiosks. In winter, one of the most popular forms of entertainment was skating at masked carnivals. Skiing was not developed in Harbin, because there were no mountains in the immediate vicinity of the city, and on the outskirts,

1 The teplushka was a warm room with a stove. The word "teplushka" itself denoted a teplushka wagon. 
where the sport could be developed, one could find the Hongkhuz ${ }^{1}$ (Kozlowski, 1979, p. 230).

In 1936, A. Upshinsky described winter entertainment in Harbin in the magazine Rubezh (Frontière): "The Sungari is very popular with the people of Harbin. When it gets a little warmer after a harsh fanuary, the people of Harbin come to the river to see what it looks like in winter clothes, to take a ride on the high-speed pull-push boats, and most importantly, to ride dizzyingly down the ice slides, And then, having ridden and laughed enough and gained an appetite in the fresh air, enjoy a shot of vodka with dumplings or juicy pancakes at the restaurant "Grandpa the winemaker" or 'Stop-Signal'"2 (See (Kozlowski, 1979, p. 230)).

Petrenko A. in his letter (1994) describes his stay in Harbin: "In January we were in Harbin for ten days - we went out to "get some air". We stayed at hotel in the former Police Street in the vicinity of the yacht club, which keeps its original form. There is an ice slide, but without the reverse. Full of sledding, not the push-pull type, but on horseback... We ate fried yams, tahoods, sticky candies: in general, I remembered my childhood and youth" (Petrenko, 1995, p. 93).

It is important to note that since the transition of CER to the SovietChinese government (1924-1925) in everyday life of leading Soviet workers of consulate, trade mission, administration of CER and other Soviet institutions the service to "Bolshevik ideals" were successfully combined with quite bourgeois ways of life and circle of interests. Luxury mansions with servants, yachts, horse-breeding, restaurants became the norm of life for most of the Soviet nomenclature in Harbin (Pisarebskaya, 2000, p. 61).

1 Hongkhuz (in Russian: хунхузы - armed bandits), who lived in the forests of Manchuria, posed as Chinese fur trappers. They were part of the community and continued to plunder for a long time. "In the great mountain forests the Baron often encountered outlaw gangs of horrible Hungkhuz, but they always proved to be very good-natured, compliant. For the most part these gangs consist of people who did not get along with society in one way or another, - wrote F. Nansen. - And the Baron believes that many of them were first engaged in illegal gold mining, ie, sought and found in these remote places along the rivers of gold sand and secretly washed it without paying anything to the government. As they gradually climbed deeper and deeper, they finally, for lack of food, turned to robbery and took in various other vagabonds and criminals who, for one reason or another, were attracted by this free life" (Nansen, 1969, p. 224). The Hungkhuzes were not solely outlaws; they included gardeners, gardeners, hunters, fishermen, etc. (Nansen, 1969, p. 226). They conducted their activities in fortified camps, in the forest wilds, high in the mountains, during the spring and all summer until the onset of the snows. The Hungkhuz dispersed in advance of winter, dividing their summer earnings in various directions, and were peaceful workers or rentiers until the beginning of spring (Nansen, 1969, p. 225).

2 In the winter in the Zaton district, the restaurants "Grandfather Winemaker" and "Stop Signal" were the only loci where many Harbiners gathered, music played, and kitchens worked (Kozlowski, 1979, p. 230). 


\section{TROTTING HARBIN OR RUNNING ON THE SUNGARI PLATEAU}

Horseback riding was considered very prestigious, and riding lessons have been popular for centuries. Horse racing is not an English invention but it was globalized through British colonization. There are many different equestrian competitions in history, such as chariot races in ancient Greece and Rome or races in the wild steppes of Mongolia (Lemon, 2008, pp. 2-3). Similar types of competitions can be found in many cultures. The concept of hippodrome space created in ancient Greece penetrated very quickly into various societies in the seventeenth century. Horse racing was a sport that could be easily organized by British officers in the colonies where a different culture prevailed. By the end of this century, English racehorses and Englishstyle horse racing were common in Europe, Asia, India, North and South Africa, Australasia, and the two American continents (Lemon, 2008, p. 5). For example, in the large Japanese port city of Yokohama, the area where the British ${ }^{1}$ lived in the 1860s, horse racing was held. Even today Japan has one of the most influential horse racing industries in the world, shaped by the English model (Lemon, 2008, pp. 6-7).

In Tianjin, as in Yokohama, the British were actively engaged in horse racing and horse breeding, combining this hobby with the promotion of their companies in the local market. Colonel G. V. Enborisov, a Menshevik Cossack in the Russian army, described a meeting with the Russian wife of an Englishman, Peters, who had a mansion near the racecourse in Tianjin: "Reception room, striking surroundings, film-worthy, canaries, parrots, comfort, smartly dressed servants, fruit, wine, cigars, etc.. Mr. Peters, plays a great role not only in town affairs, but also in the shipping company, hippodrome and other enterprises, which undoubtedly need people; and their estate, or rather castle, is near the hippodrome, surrounded by a huge garden - park and outbuildings... Leaving the castle, I looked around it, and involuntarily recalled the Great Russia"(Yenborisov, 2014, p. 183).

If the space of the Harbin Yacht Club emerges at the initiative of the railway workers, the space of the racecourse was created at the suggestion of the Russian Cossacks. It cannot be said that the Harbin Hippodrome was built exclusively according to the English model, because Russian Cossacks, railroad workers, officers, as well as Chinese, Japanese, and Europeans took part in the creation of this space.

1 The American commander Matthew Perry presented the railroad project in Japan in 1854, and the British built the first Japanese railroad from Tokyo to Yokohama. Construction of the $29 \mathrm{~km}$. railroad was completed in 1872 . The railroad was initially managed by both the British and Japanese (Free, 2008, pp. 59-60), (Tang, 2014, pp. 863-864). 
In 1910 in Harbin a military racing association was established with six horse regiments of the Zaamursky region of the Separate Corps of Border Guards. "Our cherished dream has come true thanks to our District Chief Lieutenant General Chichagov and his Chief of Staff, Major General Volodchenko, these cavalrymen are great lovers of horse sport...we unfortunately do not have good officer horses in the District and it is difficult to get them here. I am sure we will get them from Russia, thanks to the care of our founders, and we will also get the racecourse of the former Harbin Racecourse Association. The first races will take place on May 6" (Poto, Military Race Society in the Far East, 1910, p. 415).

The railroad link between Harbin and Vladivostok took place in 1901 (Krasnov, 1903, p. 65). From that moment the "iron horse" became the main symbol of the conquest of the vast expanses of Siberia and the Far East instead of the Cossack horse and Cossacks. "I confess, at that time it pained me to realize that the Cossacks were becoming obsolete and that the time was not far off when the Cossacks would be abolished, just as the streltzys ${ }^{1}$, hussars, lancers and many others were abolished... And again I heard expressions - Cossacks have lived out their time and now there are no people with such mastery around their horses", - the Russian general P. N. Krasnov wrote in 1901 (Krasnov, 1903, pp. 25-26). The competitions at the Harbin Hippodrome were an opportunity for many Cossacks to fit into a new space and to consolidate their cultural heritage in the memory of Russian society in a new territory.

One of the first impressions of Manchuria among the Russians who came to build the railroad was the stunted Mongolian horses ${ }^{2}$ of the local population. In turn, the Manchus marveled at the friskiness of the Cossack guards' horses and their obedience to their masters. Bringing horses from Russia was one of the most important things the builders of the CEL did to establish their way of life $\mathrm{e}^{3}$. These horses were intended for construction managers, their beauty and agility were admired by the local population (Zentka, 1998, p. 224). The assistant chief of CEL section Moskovitin G. S. wrote in his letter in 1899: "There is only one pleasure - it is riding, each of us has a riding horse and here when we roam several people together we send our horses to gallop and fly along ... I have a very expensive horse, a young

1 Streltsy (in Russian: стрельцы) were the units of Russian firearm infantry from the 16th to the early 18th centuries and also a social stratum, from which personnel for Streltsy troops were traditionally recruited. They are also collectively known as streletskoye voysko (in Russian: стрелецкое войско). These infantry troops reinforced feudal levy horsemen or pomestnoye voysko (in Russian: поместное войско).

2 Russian General Krasnov P. N. noted that "the Mongol horse is not nimble. It can do 100 versts (1066,9 meters) in a day, but not 60 in five hours. It is not fastidious for fodder, but on bad fodder it is weak, it is shallow... and soon it is difficult to work on it" (Krasnov, 1903 p. 275).

3 At the end of the 19th century, Kuban, Don and Mongol horses could be found in Northern Manchuria (Krasnov, 1903, p. 64). 
Cossack ... and I use this horse since my first days here, it got used to me ... I have only one this hobby, I will sometime film my horse and send it for you to see, it trots really well' (Archival file, 25, pp. 3-5).

Russian officers and Cossacks have always sought to ride only thoroughbred horses and complete their regiments with such stallions.

The higher was the status of the officer, the higher was the origin of the stallion (Yaphimovich, 1910, p. 244). For example, a thoroughbred racehorse is considered "English breed" only if it has been bred under the direction and supervision of several generations of Englishmen in England (Lemon, 2008, p. 4). The Cossack trotter, unlike the "working" horses, was kept in special conditions, just like any other racehorse, in a well-equipped room and was much better fed and not harnessed to transport cargo (Kochetov, 2017, p. 38). The trotters of the border guards in Northern Manchuria were mainly battle horses, prepared for military action and difficult climatic conditions. It is no coincidence that it was the Cossacks who were very successful in competitions at the Harbin racecourse.

The Russian army in Manchuria also used Mongolian horses in cases when the regiment lacked funds and could not import and renew trotters from Russia. The Trans-Amur Regiment of the Separate Border Guard Corps, stationed in Harbin, used Transbaikalian and Mongolian horses (Poto, 1910, pp. 37-38).

The races in Harbin were held as early as 1906, even before the construction of the hippodrome began. Sometimes they were organized to raise funds for the Harbin Charitable Society (Bugs and bounces, 1906, p. 1). In 1909 the Society for the Encouragement of Horse-Breeding was established and a hippodrome was built at 48 Gogolevskaya Street, in the Modjagou district (Ternavsky, 1926, p. 194). The racecourse included various spaces - the cafe "Hippodrome", grandstands with carved wooden decorations, a restaurantrotunda with a colonnade, a brass band, a track and a bell at the start. The racecourse became a place not only for fans' gambling conversations, but also for business meetings and acquaintances (Zentka, 1998, pp. 224-225).

During this period of time, sport for the Russians was associated primarily with horses. Riding a horse "with a breeze", traversing Russian territories on it was part of national culture for many centuries. There is no doubt that in Russian culture the productive power of the horse, is interconnected with the productive power of the man. In Harbin, expensive trotters pulling carriages, baby carriages and sleighs began to appear more and more often - the so-called "outings". At these "outings" one could see road managers and wealthy people accompanied by ladies in boas and long dresses, with umbrellas and extravagant hats. During the period of the commercial boom, the importation of horses from Russia was put on 
a "wide footing", and wealthy Chinese started driving such carriages too. Horse breeders and jockeys began to bring in Orlov trotters of pure blood with a known pedigree (Zentka, 1998, p. 224). In the 19th century the desire of jockeys to transport their horses between continents was nothing new. These journeys were very tedious, dangerous, and expensive, but these factors were not an obstacle, as a large wager could compensate for the transportation (Lemon, 2008, p. 8).

The American sociologist Veblen R. points out that with riding horses the case is almost the same as with dogs. They are generally expensive, wasteful and useless for productive purposes. The use of a horse, which would, if it were productive, increase the welfare of society or make people's lives easier, is a demonstration of strength and ease of movement, satisfying the aesthetic tastes of society. The economic profitability of a riding horse lies largely in its effectiveness as a means of competition: when a horse owner causes their horse to overtake their neighbor's horse, it gives this individual a sense of conquest and domination (Veblen, 1984, p. 165). Keeping a racehorse is a low-profit affair, in most cases wasteful, but it is an honorable activity, it enhances the owner's reputation, and satisfies the need for gambling.

The fat cats of the city and the road, merchants and industrialists considered it prestigious to exhibit their horses at the competition. Newspaper articles reported on the winners and their owners. Mutual congratulations were expressed in offices and at banquets, and arguments of fans were heard everywhere.

Later there were boarding stables with trainers who came from Russia. Some wealthy people had several horses each. Horse breeders also came along. One of the first horse breeders was the road manager L. D. Khorvat. The Chinese also began to buy horses - those were the employees of the Road Administration, and merchants - they began to "cheer" for their horses with the inherent passion of the Chinese nation. The results of the horses' speed were compared with the results of the famous horses on the racecourse of Russia. The names of the riders and horse owners could be heard among the audience, and the stands fell silent at the start.

In addition to traditional horse races, Cossack-style horse riding, "Dzhigitovka" , was very popular among Harbin residents and foreigners (Zentka, 1998, p. 225). Dzhigitovka is an exclusively Cossack tradition that came to Harbin with the arrival of Cossacks in Northern Manchuria.

1 The Jigitovka was a galloping race on a horse, during which riders showed their dexterity in controlling the horse and wielding weapons. Dzhigitovka included shooting and cutting, picking up objects from the ground, jumping and jumping on a horse at a quarry, and turning over on a gallop facing backwards. Dzhigitovka was an obligatory part of the training of the Cossack warrior and was widespread in all Cossack troops (Bogutsky, 2012, p. 44). 
After the Russian Civil War, some Cossack riders earned money touring and performing in Europe, Asia, and North and South America (Bogutsky, 2012, p. 45). Thus, on the initiative of the Russian Cossacks in Manchuria, a new sporting competition appeared. Some Cossacks traveled around the world with their performances. In 1923, Cossacks demonstrated their art in the Philippines and Japan. After reorganization of Security guard of CEL the Cossacks who stayed in Harbin bought horses for themselves to earn money as carriage drivers and for work at forest concessions. Some went to work in private firms and government institutions. Often Cossacks were hired as jockeys (Lavrentyev, 1943, p. 84).

Russian riders and trotters were highly valued by the Chinese elite. There were three races per day at the Harbin Hippodrome. The trotters were called by various names and nicknames: "Miss Wilkes", "Marutsina", "Kitayanka", "Atamanka", "Orlenok", "Surf”, "Apollo", "Zabiyaka", "Vampire", "Diamond", "Miss Cat", "Valencia" and many others (Hippodrome today (running day program), 1930, p. 5), (Harbin on the run, 1930, p. 4). For example, the trotters "Valencia" and "Vityaz" had jockeys Myatelev and Pak, and the horses belonged to the chairman of the Board of the CEL, Liu Junhuang. During the summer season the grandstands of the hippodrome were filled to capacity, the sweepstakes and sweepstakes (Harbin at the racetrack, 1930, p. 5) were very lively. During the rains all racing and racing was canceled (At the racetrack, 1930, p. 5). During the holidays there were 22 to 24 races. The racing season ended at the end of December (p. 5).

The program of the races consisted of several stages: races for lower ranks of frontier guards and Chinese soldiers; jigging of Cossacks and lower ranks of frontier guards; running handicap; competitions for saddle-hunters on horses of all breeds except thoroughbreds; gentlemen race (Bugs and bounces, 1906, p. 1). The racecourse, like many other spaces in Harbin, was a place of communication between Russians and Chinese.

It is noteworthy that the racecourse was first built outside the city (behind the Modiagou River), when the Modiagou area had not yet been designed (Map, Harbin City Plan, 1911), but a few years after the growth of Harbin, a garden city project (the Central garden and its outskirts) was laid on this site (Map, City Plan of Harbin and Fujadian, 1931), (Map, Diagram of the Harbin Knot, 1922) and as a result, after 1933 the racecourse was moved further south to the area of Old Harbin behind Hospital Town, i.e. the racecourse was positioned as a suburban space that was built on the outskirts of the city (Map, General plan of Harbin, 1938), (Map, The Japanese map of Harbin, 1939), (Map, Plan of the Great Harbin City, 1933). The hippodrome was probably planned to be included in the overall urban landscape, but the real situation forced to move this space to the outskirts of the city. 
The racecourse space was rebuilt several times (Koyirenko N.; Hongwei Yang; Ivanova, A., 2015, p. 157), and was transferred to another location. The racecourse business developed and existed under all regimes until 1949. The Japanese during the occupation of Manchuria in 1931 built a new racecourse with reinforced concrete stands. They began to breed an improved breed of horses by crossing local small horses with large ones and testing them at the racecourse. By 1945, only the European population in Harbin was interested in horse breeding.

\section{CONCLUSION}

It is indicative that the heterotopic spaces of the Yyacht club and the Racecourse offered a new way of life in Manchuria and expressed the idea of forming a new human being. Within these spaces, many cultural processes took quite different forms. These two social institutions were formed by two professional communities - railway engineers and Cossacks of the CEL Border Guard.

The yacht club and the racecourse are heterotopic spaces because the ideas of modeling these places were borrowed from Russian, Chinese, British, American and other cultures. Any heterotopy implies the presence and concentration of a plurality of cultures in one place. As a rule, heterotopy can appear in any culture.

The spaces of the racecourse and the yacht club have clearly functioned as recreational spaces in the process of building and developing Harbin society for several decades. Despite the variability of leisure spaces in public discourse, a number of functions are assigned to these spaces in any society in different eras. In the process of this study, I have identified three functions: communicative, reactive, and competitive. The racecourse and the yacht club were clearly "other spaces" in relation to the ordinary leisure establishments of Harbin, but these two spaces were interconnected with other locations of the city - streets, the waterfront, apartment buildings, etc. They formed a completely different city and urban life, which in the first half of the twentieth century differed significantly from everyday life in Russian and Chinese cities.

For many years the yacht club was perceived by Harbin residents and tourists as the best place for recreation. It combined several spaces - shore, beach, promenade, Sungari River, veranda, garden, restaurant, sports grounds, etc. The racecourse space though it was created primarily for spectacles also included many different spaces. In turn, these interior spaces also incorporated many different spaces: entrances and exits, stairs, paths, shrub alleys, kiosks, dressing rooms, seating areas, kitchens, cashiers, sailing piers, parking lots, yachts, boats, courts, stables, observation decks, and many more. 
In leisure spaces, as in many others, time is very regulated. Heterochrony in these places will differ depending on the function of the space, cultural characteristics, frontier situation, seasonal cyclicality, decisions of the ruling elites, and many others.

The Yacht Club was primarily an open space for the entire population of Harbin - the waterfront and beach were accessible to all. The yacht club's restaurant also suggested openness, but offered a limited number of seats. There were no bans on entering these spaces. Both the Yacht Club and the racecourse had spaces that suggested accommodation for the elite. The racecourse was positioned more as an enclosed space with strict rules the access to the field was limited, the grandstands were strictly organized. As a rule, the river was an open space, while the racecourse was a confined and closed place.

\section{ACKNOWLEDGEMENTS}

I would like to express my enormous gratitude to Serguey Yakushenkov for his support, patience, advice, time spent on my seven-year training at Astrakhan State University, and his help during this and other studies. From the very beginning of my scientific research in 2013 Serguey Yakushenkov has been my mentor in the world of science. His advice and guidance played a crucial role in shaping my scientific interests. Many observations that the reader will find in the pages of this article, I could not have made without the advice of Luke Jeske, Elina Sarakaeva, Dan Ben-Kanan, Alexander Semenov, and Tatiana Borisova. I would especially like to thank Oleg Antropov and Edward Denison for their help in finding materials. The writing of this study was made possible by the support of the Oxford Russian Found in 2020-2021.

\section{References}

A map of the city of Harbin (japanese map). (1939). Harbin.

Ablamsky, V. P. (1998). Russian Sport in Harbin. Manuscript. Vikhorevka Irkutsk region. 1994. E. P. Taskina (Ed.), Russian Harbin (pp. 219-220). Moscow: Publishing house of Moscow University "CheRo" (in Russian).

All for fishing. (June 15, 1929). Rubezh (Frontière) (25 (74)), 21 (in Russian).

Announcement in view of the impending opening for the summer season. (April 24, 1941). Harbin time (107 (3346)), 4 (in Russian).

At the Hippodrome. (December 4, 1930). Harbin Herald (274), 5 (in Russian).

At the racetrack. (October 2, 1930). Harbin Herald (223), 5 (in Russian).

At the racetrack. (September 17, 1930). Harbin Herald (210), 5 (in Russian). 
Avenarius, S. (1969-1979). 80 years of CEL (1898-1978). Historical Essay. Polytechnic. Jubilee collection (10), 58-64 (in Russian).

Ben-Canaan, D. (2010). Harbin Strategic Plan - Prosperity on Both Sides of the Songhua River. Script for a video information advancement. Harbin Municipal Government, 1-7.

Bogutsky, A. E. (2012). Dzhigitovka as a phenomenon of military-sports culture in Yenisei and Irkutsk Cossacks. Bulletin of N. F. Katanov Khakass State University (1), 43-47 (in Russian).

Chemodakova, O. (1978). Pictures of Harbin and the Sungari. Polytechnic. Fubilee Collection. (10), 236-238 (in Russian).

Competitions motor boats on the Sungari. (September 2, 1930). Harbin Herald (197), 5 (in Russian).

Denison, E. \& Ren, G. (2016). Ultra-Modernism: Architecture and Modernity in Manchuria. Hong Kong: Hong Kong University Press.

Diaries of the Emperor Nikolay II. 1894-1904. (2011) S. V. Mironenko (Ed.) (Vol. 1). Moscow: ROSPEN (in Russian).

For cultural leisure. (October 5, 1930). Harbin Herald (226), 9 (in Russian).

Foucault, M. (1986). Of Other Spaces. Diacritics, (1), 22-27.

Foucault, M. (2006). Intellectuals and Power: Selected Political Articles, Speeches and Interviews. Moscow: Praxis (in Russian).

Free, D. (2008). Early Japanese Railways, 1853-1914. Tokyo: Tuttle Publishing.

Harbin at the racetrack. (June 11, 1930). Harbin Herald (129), 5 (in Russian).

Harbin city plan. (1911). Harbin.

Harbin in Summer. (June 27, 1942). Rubezh (Frontière) (26), 6-7 (in Russian).

Harbin on horse races. (October 12, 1930). Harbin Herald (231), 4 (in Russian).

Horse racing and the Horse Race. (October 27, 1906). Harbin Herald, (872), 1 (in Russian).

Klyuchnikova E. (2020). Arzamas. Retrieved 2021, from Magic, balls and locomotive horns: How Pavlovsky Station Changed the History of Russian Music: https://arzamas.academy/mag/912-pavlovsk (in Russian).

Kochetov A. M. (2017). Everyday life of the Cossacks in Sholokhov's novel "The Quiet Don". Sholokhov's World (1(7)), 35-77 (in Russian).

Kozlovsky B. (1979). Notes on life in Harbin. Polytechnic. Jubilee Collection. (10), 231-233 (in Russian).

Kozlowski, B. (1979). Entertaining the outdoors. Polytechnic. Fubilee Collection (10), 229-230 (in Russian).

Kozyrenko N. Hongwei, Yang; Ivanova, A. (2015). Harbin's urban planning heritage. Khabarovsk: Pacific State University Press (in Russian).

Kradin, N. P. (2001). Harbin - Russian Atlantis. Khabarovsk: Khvorov A. Y. Press (in Russian). 


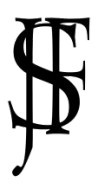

Журнал Фронтирных Исследований. 2021. No 3 | ISSN: 2500-0225

Фронтир в мировом контексте | Doi: https://doi.org/10.46539/jfs.v6i3.314

Krasnov, P. (1903). Across Asia. Travelling Sketches of Manchuria, the Far East, China, Japan and India. St. Petersburg: The printing house of Isidor Goldberg (in Russian).

Krotova M. V. (2019). The phenomenon of Harbin as a polyphonic city. Fournal of Regional History (2 (3)), 749-785.

Lavrent'ev K. I. (1943). Yenisei Cossack Troops and the Yenisei Foreign Cossack Stachina in Harbin. Bulletin of the Cossack Exhibition in Harbin, 82-85 (in Russian).

Lemon, A. (2008). Horse Racing: An English or an International Sport? B. C. McConville (Ed.), A Global Racecourse: Work, Culture and Horse sports (pp. 1-11). Melbourne: The Australian Society for Sports History.

Levoshko S. (2003). Russian Architecture in Manchuria late 19th - first half of 20th centuries. Khabarovsk: Private Collection Publishing House (in Russian).

Loulou. (31 июля 1909 г.). Feuilletons and fiction. Railway Life in the Far East (21), 845-846.

Lukoyanov I. V. (2008). “Keeping up with the Powers...”: Russia in the Far East in the late 19th early 20th centuries. St. Petersburg: Nestor-History (in Russian).

Melikhov G. V. (2003). White Harbin: The Middle of the Twenties. Moscow: Russkiy Put (in Russian).

Meshcheryakov A. Yu. Frontier case of the Russian engineer: letters of G. S. Moskvitin (1898-1901). Journal of Frontier Studies (4-1), 172-197 (in Russian). doi: 10.24411/25000225-2019-10 033

Miscellaneous News. (1895). Proceedings of the Assembly of the Railway Engineers, (8), 127-128 (in Russian).

Molodyakov, V. E. (2020). The State of Manchou-Go through the Eyes of French Analysts: From the "Manchurian Incident" (1931) to the "Chinese Incident" (1937). Ural Orientalism (10), 55-65 (in Russian).

Moser, S., Clinton, S., \& Wallach, J. (2017). Leisure Activities in Southeast Asia, from Precolonial Times to the Present. In K. Spracklen, B. Lashua, E. Sharpe, \& S. Swain (Ed.), The Palgrave Handbook of Leisure Theory (pp. 107-125). London: Palgrave Macmillan.

Nansen, F. (1969). To the country of the future. The Great Siberian Route from Europe to Siberia across the Kara Sea. Magadan: Magadan Book Publishers (in Russian).

Native Sungari. (1975). Polytechnic (7), 105 (in Russian).

On the waves of the Sungari. Yacht races for the championship of Harbin. (September 1942). Ray of Asia (97/9), 34 (in Russian).

On the Yacht Club beach sports court. (17 August 1930). Harbin Herald (186), 6 (in Russian).

Palms on the banks of the Sungari. Yacht Club summer gourmet oasis in Harbin. (1940). Rubezh (Frontière) (29), 16 (in Russian).

Petrenko, A. (1995). Excerpt from a letter by A. Petrenko. Polytechnic (14), $92-93$ (in Russian).

Pisarevskaya Y. L. (2000). Two Russia in Manchuria: Social Adaptation and Re-emigration (20s - early 30s). New Historical Herald, 52-70 (in Russian).

Plan of the City of Great Harbin. (1933). Harbin. 
Plan of the city of Harbin and Fudzjadjana. (1931). Harbin.

Poems, feuilletons and fiction. Railroad Silhouettes. (January 1, 1908). Railway Life in the Far East (2), 67-69 (in Russian).

Poteau. (15 January 1910). Cavalry in the Far East. Vestnik of the Russian cavalry (1), 37-38 (in Russian).

Poteau. (May 15, 1910). The Military Riding Society in the Far East. Bulletin of the Russian cavalry (9), 415 (in Russian).

Pozdnev, D. (1897). Description of Manchuria (Vol. 1). St. Petersburg: Printing house of Yu. N. Erlich (in Russian).

Racecourse today (running day program). (June 1, 1930). Harbin Herald (122), 5 (in Russian).

Schematic of Harbin nodal center. (1922). Harbin.

State Archives of the Astrakhan region. Found 1096. Inventory 1 (in Russian).

Sun, water and air - the joys of summer. (15 July 1945). Rubezh (Frontière) (19), 10-11 (in Russian).

Tairov M. (1974). The Wharf and the New Town. Polytechnic (6), 37-38 (in Russian).

Tang, J. P. (2014). Railroad Expansion and Industrialization: Evidence from Meiji Japan. The Fournal of Economic History (74), 863-886.

Ternavsky S. T. (1926). All of Harbin as of 1926. Address and reference book. Harbin: Printing house of Chinese Eastern line (in Russian).

The master plan of Harbin. (1938). Harbin.

The Yacht Club, as last year, will be the best place to relax. (February 27, 1941). Harbin time (54 (3293)), 6 (in Russian).

The Yacht Club. (June 6, 1930). Harbin Herald (126), 4 (in Russian).

The Yacht Club. (October 1, 1930). Harbin Herald (. 222), 4 (in Russian).

The Yamato Hotel \& The Yacht Club in Harbin. (1 august 1940 г.). Manchuria. North Manchuria Number, 342-343.

Veblen, T. (1984). The Theory of the Leisure Class: An Economic Study of Institutions. Moscow: Progress (in Russian).

Woodside, M. (2020). Frontiers of Boyhood: Imagining America, Past and Future. Norman: University of Oklahoma Press.

Yacht Club Ball. (June 7, 1930). Harbin Herald (127), 5 (in Russian).

Yacht Club competitions. (26 August 1930). Harbin Herald (192), 5 (in Russian).

Yacht Club is preparing for the season. (May 1, 1930). Harbin Herald (96), 6 (in Russian).

Yacht Club. (May 8, 1930). Harbin Herald (101), 5 (in Russian).

Yacht Club. Opening of the season. (May 18, 1930). Harbin Herald (110), 4 (in Russian).

Yacht Club. Resolution of the sports commission. (May 11, 1930). Harbin Herald (4), 6 (in Russian). 


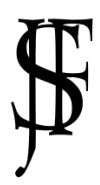

Журнал Фронтирных Исследований. 2021. No 3 | ISSN: 2500-0225

Фронтир в мировом контексте | Doi: https://doi.org/10.46539/jfs.v6i3.314

Yafimovich M. (March 30, 1910). On the thoroughbred horse and racing in the old days and nowadays. Bulletin of the Russian cavalry (6), 242-251 (in Russian).

Yakovkin, E. V. (2018). Kio-Va-Kai and Russian Emigration 1932-1945. East Asia and the changing global world order. V international conference of young orientalists, 217-223 (in Russian).

Yakushenkov S. N. (2019). In frontier we trust. Fournal of frontier studies (3), 12-59. doi: 10.24411/2500-0225-2019-10 018 (in Russian).

Yenborisov, G. V. (2014). From the Urals to Harbin. Moscow: Veche (in Russian).

Zentka E. F. (1998). Harbin racecourse. Manuscript. Pavlodar, 1995. E. P. Taskina (Ed.), Russian Harbin (pp. 224-226). Moscow: Publishing house of Moscow University "CheRo" (in Russian).

Zhernakov, N. N. (1969-1979). The Sungari River in the life of Harbin. Polytechnic. Jubilee issue (10), 103-104 (in Russian).

\section{Список литературы}

Ben-Canaan, D. (2010). Harbin Strategic Plan - Prosperity on Both Sides of the Songhua River. Script for a video information advancement. Harbin Municipal Government, 17.

Denison, E. \& Ren, G. (2016). Ultra-Modernism: Architecture and Modernity in Manchuria. Hong Kong: Hong Kong University Press.

Foucault, M. (1986). Of Other Spaces. Diacritics, (1), 22-27.

Free, D. (2008). Early Japanese Railways, 1853-1914. Tokyo: Tuttle Publishing.

Lemon, A. (2008). Horse Racing: An English or an International Sport? B. C. McConville (Ed.), A Global Racecourse: Work, Culture and Horse sports (pp. 1-11). Melbourne: The Australian Society for Sports History.

Loulou. (31 July 1909 г.). Фельетоны и беллетристика. Железнодорожная жизнь на Дальнем Востоке, (21), 845-846.

Moser, S., Clinton, S., \& Wallach, J. (2017). Leisure Activities in Southeast Asia, from Precolonial Times to the Present. In K. Spracklen, B. Lashua, E. Sharpe, \& S. Swain (Ed.), The Palgrave Handbook of Leisure Theory (pp. 107-125). London: Palgrave Macmillan.

Tang, J. P. (2014). Railroad Expansion and Industrialization: Evidence from Meiji Japan. The fournal of Economic History, (74), 863-886.

The Yamato Hotel \& The Yacht Club in Harbin. (1 august 1940 г.). Manchuria. North Manchuria Number, 342-343.

Woodside, M. (2020). Frontiers of Boyhood: Imagining America, Past and Future. Norman: University of Oklahoma Press.

Абламский, В. П. (1998). Русский спорт в Харбине. Рукопись. Вихоревка Иркутская область. 1994. (Ред.) Е. П. Таскина. Русский Харбин (стр. 219-220). Москва: Издательство Московского университета «ЧеРо». 
Авенариус, С. (1969-1979). 80 лет КВЖД (1898-1978). Исторический очерк. Политехник. Юбилейный сборник, (10), 58-64.

Бал яхт-клуба (7 июня 1930). Герольд Харбина (127), 5.

Бега и скачки (27 октябрь 1906). Харбинский вестник (872), 1.

Богуцкий, А. Е. (2012). Джигитовка как феномен военно-спортивной культуры у енисейских и иркутских казаков. Вестник Хакасского государственного университета им. Н. Ф. Катанова (1), 43-47.

В яхт-клуб (6 июнь 1930). Герольд Харбина (126), 4.

В яхт-клубе (1 октября 1930). Герольд Харбина (222), 4.

Веблен, Т. (1984). Теория праздного класса. Москва: Прогресс.

Все для рыбной ловли (15 июнь 1929). Рубеж (25 (74)), 21.

Генеральный план города Харбина (1938). Харбин.

Государственный архив Астраханской области. Ф. 1096. Оп. 1.

Градостроительный план Харбина (1911). Харбин.

Дневники императора Николая II. 1894-1904. (2011). (Ред.) С. В. Мироненко (Т. 1). Москва: РОСПЭН.

Енборисов, Г. В. (2014). От Урала до Харбина. Москва: Вече.

Жернаков, Н. Н. Река Сунгари в жизни Харбина. Политехник. Юбилейный выпуск (10), 103-104.

За культурный досуг (5 октябрь 1930 г.) Герольд Харбина (226), 9.

Зентка, Е. Ф. (1998). Харбинский ипподром. Рукопись. Павлодар, 1995. (Ред.) Е. П. Таскина. Русский Харбин (стр. 224-226). Москва: Издательство Московского университета «ЧеРо».

Ипподром сегодня (программа бегового дня). (1 июнь 1930). Герольд Харбина (122), 5.

Карта города Харбина (1939). Харбин.

Клуб превращен в кабак (14 июня 1930). Герольд Харбина (132), 5.

Ключникова, Е. (2020). Arzamas. Получено 2021, из Магия, балы и гудки паровозов: как Павловский вокзал изменил историю российской музыки: https:// arzamas.academy/mag/912-pavlovsk

Козловский, Б. (1979). Заметки о харбинской жизни. Политехник. Юбилейный сборник (10), 231-233.

Козловский, Б. (1979). Развлечения на свежем воздухе. Политехник. Юбилейный сборник (10), 229-230.

Козыренко, Н.; Хунвэй, Ян; Иванова, А. (2015). Градостроительное наследие Харбина. Хабаровск: Издательство Тихоокеанского государственного университета.

Кочетов, А. М. (2017). Повседневная жизнь казачества в романе М. А. Шолохова «Тихий Дон». Мир Шолохова (1(7)), 35-77. 


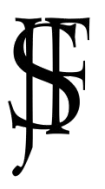

Журнал Фронтирных Исследований. 2021. No 3 | ISSN: 2500-0225

Фронтир в мировом контексте | Doi: https://doi.org/10.46539/jfs.v6i3.314

Крадин, Н. П. (2001). Харбин - русская Атлантида. Хабаровск: Издатель Хворов А. Ю.

Краснов, П. (1903). По Азии. Путевые очерки Маньчжурии, Дальнего Востока, Китая, Японии и Индии (Изд. 1). Санкт-Петербург: Типография Исидора Гольдберга.

Кротова, М. В. (2019). Феномен Харбина как полифоночного города. Журнал региональной истории (2 (3)), 749-785.

Лаврентьев, К. И. (1943). Енисейчкое казачье войско и енисейская зарубежная казачья станица в Харбине. Вестник казачей выставки в Харбине, 82-85.

Левошко, С. (2003). Русская архитектура в Маньчжурии конеи XIX - первая половина $X X$ веков. Хабаровск: Издательский дом Частная коллекция.

Лукоянов, И. В. (2008). «Не отставать от держав...»: Россия на Дальнем Востоке 6 конце XIX - начале XX вв. Санкт-Петербург: Нестор-История.

Мелихов, Г. В. (2003). Бельий Харбин: Середина 20-х. Москва: Русский путь.

Мещеряков, А. Ю. (2019). Фронтирный кейс русского инженера: письма Г. С. Москвитина (1898-1901). Журнал фронтирных исследований (4-1), 172-197. doi: 10.24411/2500-0225-2019-10033

Молодяков, В. Э. (2020). Государство Маньчжоу-Го глазами французских аналитиков: от «Маньчжурского инцидента» (1931) до «китайского инцидента» (1937). Уральское востоковедение (10), 55-65.

На ипподроме (17 сентябрь 1930). Герольд Харбина (210), 5.

На ипподроме (2 октября 1930). Герольд Харбина (223), 5.

На ипподроме (4 декабрь 1930). Герольд Харбина (274), 5.

На спорт-площадке пляжа Яхт-клуба (17 август 1930). Герольд Харбина (186), 6.

Объявление ввиду предстоящего открытия на летний сезон (24 апрель 1941). Харбинское время (107 (3346)), 4.

Пальмы на берегу Сунгари. Яхт-клуб летний оазис гурманов в Харбине (1940). Рубеж (29), 16.

Петренко, А. (1995). Выдержка из письма А. Петренко. Политехник (14). 92-93.

Писаревская, Я. Л. (2000). Две России в Маньчжурии: социальная адаптация и реэмиграция (20-е - начало 30-х гг.). Новый исторический вестник, 52-70.

План города Великого Харбина (1933). Харбин.

План города Харбина и Фудзядяна (1931). Харбин.

Позднев, Д. (1897). Описание Маньчжурии (Т. 1). Санкт-Петербург: Типограффия Ю. Н. Эрлих.

Пото (15 мая 1910). Военно-скаковое общество на Дальнем Востоке. Вестник русской конницьь (9), 415.

Пото (15 январь 1910). Конница на Дальнем Востоке. Вестник русской коннищь (1), 3738.

Разные известия (1895). Известия Собрания инженеров путей сообщения (8), 127-128. 
Родная Сунгари. (1975). Политехник (7), 105.

Солнце, вода и воздух - радости лета (15 июль 1945). Рубеж (19), 10-11.

Состязания в Яхт-клубе (26 август 1930). Герольд Харбина (192), 5.

Состязания моторных лодок на Сунгари (2 сентябрь 1930). Герольд Харбина (197), 5.

Стихотворения, фельетоны и беллетристика. Железнодорожные силуэты (1 январь 1908). Железнодорожная жизнь на Дальнем Востоке (2), 67-69.

Схема Харбинского узла (1922). Харбин.

Таиров, М. (1974). Пристань и Новый город. Политехник (6), 37-38.

Тернавский, С. Т. (1926). Весь Харбин на 1926 год. Адресная и справочная книга. Харбин: Типография Китайской Восточной железной дороги.

Фуко, М. (2006). Интеллектуалы и власть: Избранные политические статьи, выступления и интервью. Москва: Праксис.

Харбин летом. (27 июнь 1942 г.). Рубеж (26), 6-7.

Харбин на бегах (12 октября 1930). Герольд Харбина (231), 4.

Харбин на ипподроме (11 июнь 1930). Герольд Харбина (129), 5.

Хоркхаймер, М., \& Адорно, Т. (2016). Культурная индустрия. Москва: Ад Маргинем Пресс.

Чемодакова, О. (1978). Картинки Харбина и Сунгари. Политехник. Юбилейный сборник (10), 236-238.

Яковкин, Е. В. (2018). Кио-Ва-Кай и российская эмиграция 1932-1945 гг. Восточная Азия и изменения глобального миропорядка. V международная конференция молодых востоковедов, 217-223.

Якушенков, С. Н. (2019). In frontier we trust. Журнал фронтирных исследований (3), 12-59. doi: 10.24411/2500-0225-2019-10018

Яфимович, М. (30 март 1910). О чистокровной лошади и скачках в старину и ныне. Вестник русской конницы (6), 242-251.

Яхт-клуб (8 май 1930). Герольд Харбина (101), 5.

Яхт-клуб готовится к сезону (1 мая 1930). Герольд Харбина (96), 6.

Яхт-клуб, как и в прошлом году, будет лучшим местом отдыха. (27 февраль 1941). Харбинское время (54 (3293)), 6.

Яхт-клуб. Открытие сезона. (18 май 1930). Герольд Харбина (110), 4.

Яхт-клуб. Постановление спортивной комиссии. (11 мая 1930). Герольд Харбина, (104), 6. 